\title{
Determinan Praktik Transfer Pricing dengan Firm Size Sebagai Pemoderasi Pada Perusahaan Pertambangan yang Terdaftar di Bursa Efek Indonesia
}

\author{
Lina Maulida ${ }^{1 *}$ \\ Agus Wahyudin ${ }^{2}$ \\ ${ }^{1,2}$ Jurusan Akuntansi, Fakultas Ekonomi, Universitas Negeri Semarang \\ ${ }^{*}$ Corresponding author email: linamaulida98@gmail.com
}

\begin{abstract}
The purpose of this study is to analyze the effect of debt covenant, tax minimization, and audit quality on transfer pricing practice with firm size as the moderating variable. Employing purposive sampling, as much as 21 mining companies listed on the IDX in 20172019 were available for the test of hypothesis . Moderated regression analysis was used for the test of hypothesis. The results showed that debt covenants have no significant effect on transfer pricing. Tax minimization and audit quality have negative effect on transfer pricing and audit quality. In addition, firm size does not significantly moderate the relationship between debt covenant and transfer pricing, but firm size can significantly moderate the relationship between tax minimization and transfer pricing and can also significantly moderate the relationship between audit quality and transfer pricing.
\end{abstract}

Keywords: Audit Quality, Debt Covenant, Firm Size, Tax Minimization, Transfer Pricing

\begin{abstract}
Abstrak
Tujuan penelitian ini untuk menganalisis pengaruh variabel debt covenant, tax minimization, dan kualitas audit terhadap indikasi praktik transfer pricing dengan firm size sebagai variabel moderasi. Menggunakan metode purposive sampling, sebanyak 21 perusahaan tersedia untuk pengujian hipotesis. Teknik analisis dengan moderated analysis regression menujukkan bahwa debt covenant tidak berpengaruh signifikan terhadap transfer pricing, tax minimization berpengaruh negatif signifikan terhadap transfer pricing dan kualitas audit berpengaruh positif signifikan terhadap transfer pricing. Firm size tidak memoderasi signifikan hubungan debt covenant terhadap transfer pricing, namun firm size dapat memoderasi signifikan positif hubungan tax minimization terhadap transfer pricing dan juga dapat memoderasi signifikan negatif hubungan kualitas audit terhadap transfer pricing.
\end{abstract}

Kata kunci: Debt Covenant, Firm Size, Kualitas Audit, Tax Minimization, Transfer Pricing

\section{PENDAHULUAN}

Sejak diberlakukannya World Trade Organization (WTO), telah banyak negara yang tidak membatasi kegiatan operasional usahanya dikarenakan sudah terbukanya akses perdagangan antarnegara. Pada umumnya, perusahaan melakukan kegiatan operasional usaha untuk memaksimalkan laba dan meminimalkan beban pajaknya. Oleh karena itu, diperlukan perencanaan yang strategis untuk menekan beban pajak tersebut. Salah satu upaya yang dapat dilakukan perusahaan yaitu menggunakan skema transfer pricing. Praktik transfer pricing 
dapat dilakukan antar departemen perusahaan yang sama maupun antar perusahaan yang memiliki hubungan khusus seperti perusahaan induk dengan perusahaan anak di negara yang berbeda. Transfer pricing diartikan sebagai harga yang dikenakan perusahaan untuk barang, jasa, aset berwujud dan tidak berwujud yang diperdagangkan dengan anak perusahaan dan entitas afiliasinya di pasar luar negeri (Alino dan Lane, 2015).

Sejalan dengan adanya transaksi dengan pihak afiliasi, pentingnya transfer pricing dilakukan sebagai bentuk meminimalkan beban pajak dengan metode memindahkan biaya dan pendapatan perusahaan dari satu perusahaan ke perusahaan lain yang mempunyai hubungan istimewa dan tentunya yang mempunyai tarif pajak berbeda atau cenderung lebih rendah. Salah satu cara yang digunakan perusahaan misalnya dengan mentransfer utang ke perusahaan afiliasinya. Akibatnya akan menimbulkan beban bunga yang menjadi pengurang Penghasilan Kena Pajak, sehingga beban pajak menjadi semakin rendah. Penelitian ini dilakukan dengan tujuan untuk menganalisis perusahaan yang memanfaatkan regulasi perpajakan melalui skema transfer pricing dengan melihat jumlah pajak yang dibayarkan perusahaan kepada negara.

Peraturan Perpajak di Indonesia yang mengatur tentang transfer pricing terkait jenis dokumen dan informasi tambahan yang wajib disimpan oleh wajib pajak yang melakukan transaksi dengan pihak yang mempunyai hubungan istimewa dan tata cara pengelolaannya tertuang dalam Peraturan Menteri Keuangan Nomor 213/PMK.03/2016. Di samping itu, juga menggunakan Arm's Length Principle (ALP) yang berarti setiap kegiatan transaksi yang dilakukan wajib pajak harus mendasari prinsip kewajaran dan kelaziman usaha, sehingga Kementerian Keuangan meminta wajib pajak untuk membuat transfer pricing documentation. Selain regulasi di atas, terdapat UU Nomor 36 Tahun 2008 Pasal 18 yang mengatur tentang pajak penghasilan mengenai masalah hubungan istimewa dalam praktik transfer pricing, serta PER-32/PJ/2011 tentang implementasi arm's length principle dalam transaksi pihak terkait. Sebenarnya praktik transfer pricing termasuk dalam perencanaan pajak yang legal dilakukan di Indonesia jika sesuai dengan regulasi yang berlaku. Namun, jika dilakukan tidak sesuai dengan aturan dan hukum yang berlaku, maka termasuk dalam penghindaran pajak yang ilegal.

Dalam sebuah laporan investigasi yang dilakukan oleh Global Witness (LSM Internasional) tahun 2019, menyatakan bahwa PT. Adaro telah melakukan penggelapan pajak dari tahun 2009-2017 dengan cara menggunakan skema transfer pricing kepada anak perusahaannya yang terletak di Singapura yaitu Coaltrade Service Internasional Pte. Ltd., dengan menjual batu bara ke anak perusahaannya jauh di bawah harga pasar, kemudian anak perusahaan tersebut (Coaltrade Service Internasional Pte. Ltd.) menjual kembali di atas harga pasar. Akibatnya PT. Adaro akan membayar pajak lebih rendah dari kewajiban yang seharusnya dibayarkan di Indonesia, karena telah mengalihkan keuntungan kepada Coaltrade Service Internasional Pte. Ltd., yang berada di Singapura dengan beban pajak yang lebih rendah dibandingkan di Indonesia (Melani \& Tulus 2019). Praktik transfer pricing di atas telah melanggar UU Perpajakan di Indonesia yang tertuang dalam Pasal 2 Ayat (1) UndangUndang Perpajakan Nomor 11 tentang Pajak Pertambahan Nilai tentang transaksi yang berhubungan dengan transfer pricing.

Berbagai penelitian telah mengkaji determinan transfer pricing dengan hasil yang belum konsisten. Nuradila dan Wibowo (2018) dan Rosa et al., (2017) menunjukkan hasil bahwa debt covenant berpengaruh secara positif signifikan terhadap keputusan melakukan transfer pricing. Hasil sebaliknya ditunjukkan oleh Yulianti dan Rachmawati (2019) yang menyatakan bahwa debt covenat berpengaruh negatif tidak signifikan terhadap transfer 
pricing. Penelitian Alino dan Lane (2015), Septiyani et al., (2018), Refgia et al., (2017), dan Noviastika et al., (2016), menunjukkan bahwa tax minimization berpengaruh positif signifikan terhadap transfer pricing. Sementara itu, Merle et al., (2019) serta Susanti \& Firmansyah (2018) menyatakan tax minimization berpengaruh negatif dan signifikan terhadap transfer pricing. Berbeda lagi dengan penelitian Mispiyanti (2015) yang menyatakan bahwa tax minimization tidak berpengaruh signifikan terhadap transfer pricing.

Penelitian Rosa et al., (2017) dan Mayantya (2018) menunjukkan bahwa kualitas audit berpengaruh positif terhadap transfer pricing. Sedangkan penelitian Khairunisa et al., (2017) dan Eksandy (2017) yang menyatakan bahwa kualitas audit berpengaruh negatif dan siginifikan terhadap penghindaran pajak. Hasil terkait kualitas audit di atas berbeda dengan penelitian yang dilakukan oleh Erawati dan Fidiana (2020), Nugroho et al., (2018), dan Noviastika et al., (2016) yang menunjukkan hasil bahwa kualitas audit tidak berpengaruh signifikan terhadap indikasi perusahaan melakukan transfer pricing. Peran firm size pada penelitian ini sebagai variabel moderasi hubungan debt covenant, tax minimization, dan kualitas audit terhadap praktik transfer pricing.

Tujuan penelitian ini untuk menganalisis pengaruh debt covenant, tax minimization, dan kualitas audit terhadap praktik transfer pricing dengan firm size sebagai pemoderasi pada perusahaan pertambangan yang terdaftar di Bursa Efek Indonesia. Penelitian ini dilakukan dengan menggabungkan variabel-variabel penelitian sebelumnya. Orisinilitas penelitian ini terletak pada firm size yang terindikasi dapat memperkuat dan memperlemah hubungan antar variabel independen terhadap praktik transfer pricing, yang mana masih jarang dijadikan sebagai variabel moderating oleh peneliti terdahulu dalam kasus ini. Selain itu, peneliti juga menambahkan kualitas audit sebagai variabel independen yang dihubungkan dengan pemoderasi yang belum banyak diteliti sebelumnya.

\section{TINJAUAN LITERATUR DAN HIPOTESIS}

\section{Teori Keagenan (Agency Theory)}

Teori keagenan menjelaskan konflik kepentingan antara pemegang saham dan manajemen perusahaan (Jensen dan Meckling 1976). Teori ini meyakini bahwa tidak ada kecocokan antara manajemen perusahaan (agen) dengan pemegang saham/pemilik perusahaan (principal) yang dapat diperoleh dari manajemen perusahaan mengenai informasi internal dan prospek perusahaan di masa depan dibandingkan pemegang saham atau perusahaan lain. Principal menginginkan pengembalian yang maksimum atas investasi mereka, sedangkan agent mengharapkan imbalan atas pekerjaan yang telah mereka lakukan dengan pemberian insentif yang sesuai (Yulia, et al., 2019).

\section{Teori Akuntansi Positif (Positive Accounting Theory)}

Teori akuntansi positif menurut Watts \& Zimmerman (1990) menjelaskan alasan mengapa perusahaan dan pemangku kepentingan menggunakan kebijakan akuntansi untuk memprediksi kebijakan akuntansi yang akan dipilih perusahaan dalam kondisi tertentu. Variabel yang digunakan dalam penelitiannya sebagian besar mencerminkan motivasi manajemen untuk memilih metode akuntansi berdasarkan rencana bonus, kontrak utang, dan prosedur politik. Menurut teori akuntansi positif, prosedur akuntansi yang digunakan oleh perusahaan tidak harus sama dengan yang lainnya, namun perusahaan diberi kebebasan untuk 
memilih alternatif yang ada untuk meminimalkan biaya kontrak dan memaksimalkan nilai perusahaan.

\section{Transfer Pricing}

Hartati et al., (2015) mengartikan transfer pricing sebagai harga yang terkandung pada setiap produk atau jasa dari satu divisi ke divisi lain dalam perusahaan yang sama, atau antar perusahaan yang mempunyai hubungan istimewa. Pada penelitian ini, variabel transfer pricing diukur dengan proksi Related Party Transaction (RPT) yang mana raiso piutang pihak berelasi terhadap total piutang perusahaan. Pengukuran tersebut sesuai dengan proksi yang digunakan oleh beberapa peneliti terdahulu, salah satunya adalah penelitian Nuradila dan Wibowo (2018).

\section{Debt Covenant}

Menurut Cochran dalam Rosa et al., (2017) mengartikan debt covenant sebagai kontrak yang ditujukan kepada pimpinan oleh kreditur untuk membatasi aktivitas yang mungkin merusak nilai pinjaman dan recovery pinjaman. Penelitian Sari dan Mubarok (2018), mendefinisikan debt covenant (kontrak utang) merupakan perjanjian untuk melindungi pemberi pinjaman dari tindakan-tindakan manajer terhadap kepentingan kreditor, seperti pembagian deviden yang berlebihan, atau membiarkan ekuitas di bawah tingkat yang telah ditentukan. Pada penelitian ini, proksi yang digunakan oleh variabel debt covenant yaitu menggunakan debt to equity ratio (DER).

\section{Tax Minimization}

Hartati et al., (2015) mengartikan tax minimization sebagai suatu strategi untuk meminimalkan beban pajak terutang melalui tindakan transfer biaya dan pada akhirnya transfer pendapatan ke negara dengan tarif pajak yang rendah. Jacob (1996) dalam penelitian Septiyani et al., (2018) menemukan bahwa transfer antara perusahaan besar dapat menyebabkan pembayaran pajak global yang lebih rendah secara umum. Pada penelitian ini, penulis menggunakan proksi Effective tax rate (ETR) untuk mengukur tax minimization.

\section{Kualitas Audit}

Simanjuntak (2008) menjelaskan bahwa kualitas audit merupakan pemeriksaan yang dilakukan secara sistematis dan menjaga sikap independen ketika melakukan suatu pekerjaan audit, menjaga mutu dan output yang dihasilkan sesuai dengan pengaturan yang telah direncanakan. Variabel kualitas audit diukur menggunakan variabel dummy, yang mana apabila laporan keuangan perusahaan diaudit oleh Kantor Akuntan Publik (KAP) Big Four bernilai 1, dan apabila laporan keuangan perusahaan diaudit oleh KAP Non Big Four bernilai 0. Pengukuran ini sejalan dengan penelitian Erawati dan Fidiana (2020) dan Nugroho et al., (2018).

\section{Firm Size}

Firm size merupakan ukuran besar kecilnya suatu perusahaan. Sementara itu, penelitian Nugroho et al., (2018) mendefinisikan firm size sebagai skala seberapa besar atau kecil suatu perusahaan yang dapat menunjukkan stabilitas, keseimbangan, dan kemampuan perusahaan dalam melakukan aktivitas ekonominya. Proksi pada penelitian ini sama dengan yang 
digunakan dalam penelitian Nugroho et al., (2018); Septiyani et al., (2018); dan Fuadah dan Nazihah (2019). Variabel firm size diukur menggunakan Log natural Total Assets.

\section{Debt Covenant dan Transfer Pricing}

Debt convenant hypothesis dalam teori akuntansi positif menjelaskan jika utang perusahaan semakin tinggi, maka syarat-syarat yang diajukan oleh kreditur juga semakin ketat. Oleh karena itu, semakin besar pula peluang para manajer untuk memilih metodemetode akuntansi yang dapat meningkatkan profit perusahaan, misalnya dengan praktik transfer pricing. Penelitian yang dilakukan Nuradila dan Wibowo (2018) dan Rosa et al., (2017) menyatakan debt covenant berpengaruh positif terhadap transfer pricing.

Berdasarkan pemikiran di atas dan hasil-hasil penelitian sebelumnya, hubungan debt covenant dan transfer pricing dapat dinyatakan sebagai berikut:

\section{H1: Debt covenant berpengaruh positif terhadap indikasi praktik transfer pricing.}

\section{Tax Minimization dan Transfer Pricing}

Perusahaan multinasional yang mendapatkan laba akan memindahkan pendapatannya ke negara dengan tarif pajak tinggi ke negara dengan tarif pajak lebih rendah. Sehingga semakin tinggi tarif pajak suatu negara, semakin tinggi pula upaya perusahaan dalam perencanaan pajak melalui tax minimization untuk melakukan transfer pricing. Tax minimization dapat menimbulkan konflik keagenan antara pemerintah sebagai pihak pricipal dengan perusahaan multinasional sebagai agen (Septiyani et al. 2018). Perusahaan multinasional menganggap pajak sebagai beban bagi perusahaan. Oleh karena itu, perusahaan berupaya untuk mengurangi kewajiban pajaknya melalui perencanaan pajak dengan memanfaatkan lubang hukum yang ada, salah satunyanya melakukan transfer pricing. Akibatnya, pemerintah kehilangan sumber pendapatannya dari pajak dan perusahaan mendapatkan kepentingannya sendiri dengan laba yang tinggi. Penelitian sebelumnya telah dilakukan Merle et al., (2019) yang menunjukkan bahwa effective tax rate berpengaruh negatif signifikan terhadap intensitas transfer pricing. Hal ini didukung Susanti dan Firmansyah (2018) yang menunjukkan beban pajak pengaruh negatif dan signifikan terhadap keputusan perusahaan dalam melakukan transfer pricing.

Berdasarkan argumen di atas dan hasil-hasil penelitian sebelumnya, hubungan tax minimization dan transfer pricing dapat dinyatakan sebagai berikut:

\section{$\mathrm{H}_{2}$ : Tax minimization berpengaruh negatif terhadap indikasi praktik transfer pricing.}

\section{Kualitas Audit dan Transfer Pricing}

Kualitas audit didasarkan atas pertimbangan yang meliputi beberapa komponen yang ada di dalam GCG yaitu, keterbukaan, kejujuran dan akuntabilitas (Rosa et al. 2017). Sering kali, ukuran suatu KAP dihubungkan dengan reputasi KAP, yang mana diduga mempunyai pengaruh terhadap kualitas audit yang dihasilkan. KAP Big 4 menghasilkan kualitas audit yang lebih tinggi dibandingkan dengan KAP Non Big 4 (DeAngelo 1981). Dalam teori keagenan, untuk menghasilkan audit yang berkualitas, seorang principal akan cenderung menunjuk agen (auditor) yang mempunyai independensi. Auditor yang mempunyai independensi tinggi diduga auditor yang berada dalam lingkup KAP yang besar. Apabila suatu laporan keuangan perusahaan diaudit oleh KAP The Big 4, maka perusahaan cenderung 
akan semakin transparansi dalam melaporkan hal mengenai pajak, sehingga praktik transfer pricing dalam perusahaan akan semakin rendah. Penelitian Eksandy (2017) menunjukkan hasil bahwa kualitas audit yang diaudit oleh KAP The Big 4 berpengaruh negatif dan signifikan terhadap penghindaran pajak.

Berdasarkan argumen di atas dan hasil-hasil penelitian sebelumnya, hubungan kualitas audit dan transfer pricing dapat dinyatakan sebagai berikut:

\section{H3: Kualitas audit berpengaruh negatif terhadap indikasi praktik transfer pricing.}

\section{Firm Size, Debt Covenant dan Transfer Pricing}

Semakin besar firm size, maka semakin tinggi daya saing yang dilakukan oleh perusahaan. Hal ini dapat dilihat dari total utang terhadap total ekuitasnya. Semakin rendah debt to equity ratio yang dimiliki perusahaan, maka semakin bagus perusahaan itu dalam memenuhi kewajiban jangka panjangnya. Sesuai dengan the debt covenant hypothesis dalam teori akuntansi positif yang menyatakan bahwa perusahaan yang mempunyai rasio utang tinggi, akan semakin besar peluang manajer dalam meningkatkan laba perusahaan dengan memilih metode akuntansi yaitu dengan melaporkan perubahan laba periode berikutnya ke periode sekarang (Rosa et al. 2017). Seiring waktu, laba perusahaan terus meningkat sesuai dengan semakin meningkatnya firm size. Para manajer dituntut bagaimana caranya agar laba perusahaan selalu tinggi agar citra dari perusahaan tersebut tetap baik. Hal ini menunjukkan bahwa firm size mampu memoderasi hubungan debt covenant terhadap transfer pricing.

Berdasarkan argumen di atas peran firm size sebagai variabel pemoderasi debt covenant dan transfer pricing dapat dinyatakan sebagai berikut:

\section{H4: Firm size mampu memoderasi secara positif pengaruh debt covenant terhadap}

\section{indikasi praktik transfer pricing.}

\section{Firm Size, Tax Minimizaton, dan Transfer Pricing}

Menurut Rego dalam Septiyani et al., (2018) menyatakan bahwa firm size yang besar akan mempengaruhi laba perusahaan secara optimal jika dibandingkan dengan firm size yang kecil, sehingga lebih cenderung melakukan manajemen laba karena perusahaan dianggap memiliki sistem manajemen yang lebih kompleks dan laba yang lebih tinggi. Akibatnya pajak terutang perusahaan juga semakin tinggi. Oleh sebab itu, manajer perusahaan cenderung menggunakan cara untuk meminimalkan pajak melalui praktik transfer pricing. Selaras dengan teori keagenan yang menyatakan adanya asimetri informasi antara prinsipal dengan agen. Firm size yang besar dianggap lebih terpercaya, sehingga memicu manajer (agen) dalam memanfaatkan aturan perpajakan untuk kepentingan perusahaan dalam memaksimalkan laba melalui tax minimization yang dibayarkan, tanpa memperdulikan atau melihat dari sisi pemerintah. Sementara, pemegang saham (prinsipal) menginginkan manajemen (agen) agar perusahaan mempunyai penilaian yang baik dan memberikan manfaat bagi para pemegang saham. Hal ini menunjukkan bahwa firm size mampu memoderasi hubungan tax minimization terhadap transfer pricing.

Berdasarkan argumen di atas peran firm size sebagai variabel pemoderasi tax minimization dan transfer pricing dapat dinyatakan sebagai berikut: 


\section{H5: Firm size mampu memoderasi secara positif pengaruh tax minimization terhadap}

\section{indikasi praktik transfer pricing.}

\section{Firm Size, Kualitas Audit, dan Transfer Pricing}

Firm size menunjukkan besar kecilnya suatu perusahaan dalam menjalakan kegiatan operasionalnya. Jika firm size besar, maka perusahaan lebih cenderung menggunakan reputasi Kantor Akuntan Publik (KAP) yang mempunyai rating teratas dunia yaitu KAP The Big 4. Hal ini sesuai dengan teori keagenan (agency theory), seorang principal akan cenderung menunjuk auditor (agent) yang mempunyai independensi untuk menghasilkan audit yang berkualitas. Apabila suatu laporan keuangan perusahaan diaudit oleh KAP The Big 4, maka perusahaan cenderung akan semakin transparansi dalam melaporkan hal mengenai pajak. Dengan begitu, maka semakin sulit perusahaan melakukan praktik transfer pricing yang tidak sesuai dengan regulasi yang ada dikarenakan reputasi auditor dapat mencerminkan seberapa besar independensi dan profesionalisme auditor dalam mengaudit laporan keuangan suatu perusahaan. Hal ini menunjukkan bahwa firm size mampu memoderasi hubungan kualitas audit terhadap transfer pricing.

Berdasarkan argumen di atas peran firm size sebagai variabel pemoderasi kualitas audit dan transfer pricing dapat dinyatakan sebagai berikut:

\section{H6: Firm size mampu memoderasi secara negatif pengaruh kualitas audit terhadap indikasi praktik transfer pricing.}

\section{METODE PENELITIAN}

\section{Populasi dan Sampel}

Penelitian ini termasuk dalam pendekatan kuantitatif. Data penelitian menggunakan data sekunder dari laporan tahunan dan laporan keuangan perusahaan pertambangan yang telah diaudit dan terdaftar sebagai perusahaan go public di Bursa Efek Indonesia tahun 20172019 sebanyak 47 perusahaan sebagai populasinya. Sampel dipilih menggunakan teknik purposive sampling sesuai dengan tabel 1 berikut.

Tabel 1. Kriteria Pengambilan Sampel

\begin{tabular}{|c|c|c|}
\hline No & \multicolumn{1}{|c|}{ Kriteria } & Jumlah \\
\hline 1. & $\begin{array}{l}\text { Perusahaan pertambangan yang terdaftar di Bursa Efek } \\
\text { Indonesia tahun 2017-2019 }\end{array}$ & 47 \\
\hline 2. & $\begin{array}{l}\text { Perusahaan pertambangan yang tidak mempublikasikan Annual } \\
\text { Report tahun 2017-2019 }\end{array}$ \\
\hline 3. & $\begin{array}{l}\text { Perusahaan pertambangan yang mengalami kerugian tahun } \\
2017-2019\end{array}$ & (20) \\
\hline
\end{tabular}




\begin{tabular}{|c|c|}
\hline $4 . \quad \begin{array}{l}\text { Perusahaan pertambangan yang tidak mengungkapkan piutang } \\
\text { dengan pihak berelasi }\end{array}$ & (4) \\
\hline Jumlah perusahaan sampel & 63 \\
\hline Jumlah unit analisis penelitian (21 perusahaan x 3 tahun) & 12 \\
\hline Data outlier yang dieliminasi dari penelitian & 51 \\
\hline Jumlah akhir observasi perusahaan selama 3 tahun (2017-2019) & \\
\hline
\end{tabular}

Sumber: Data sekunder yang diolah, 2021

Transfer pricing berperan sebagai variabel dependen dalam penelitian ini. Sementara debt covenant, tax minimization, dan kualitas audit berperan sebagai variabel independen. Penelitian ini juga menambahkan firm size sebagai variabel moderasi yang menghubungkan antara debt covenant, tax minimization, dan kualitas audit terhadap transfer pricing. Definisi operasional variabel dapat dilihat pada tabel 2 berikut.

Tabel 2. Definisi Operasionalisasi Variabel

\begin{tabular}{|c|c|c|c|}
\hline NO & VARIABEL & DEFINISI OPERASIONAL & PENGUKURAN \\
\hline \multirow[t]{2}{*}{1.} & \multirow[t]{2}{*}{$\begin{array}{l}\text { Transfer } \\
\text { Pricing }\end{array}$} & \multirow{2}{*}{$\begin{array}{l}\text { Transfer pricing adalah } \\
\text { harga yang terkandung pada } \\
\text { setiap produk atau jasa dari } \\
\text { satu divisi ke divisi lain } \\
\text { dalam perusahaan yang } \\
\text { sama, atau antar perusahaan } \\
\text { yang mempunyai hubungan } \\
\text { istimewa (Hartati et al., } \\
\text { 2015). }\end{array}$} & $\begin{array}{l}\text { Related Party Transaction }(\mathrm{RPT})= \\
\text { Piutang Pihak Relasi X } 100 \%\end{array}$ \\
\hline & & & $\begin{array}{c}\text { Total Piutang } \\
\text { (Nuradila \& Wibowo, 2018) }\end{array}$ \\
\hline 2. & $\begin{array}{l}\text { Debt } \\
\text { Convenant }\end{array}$ & $\begin{array}{l}\text { Debt covenant adalah kontrak } \\
\text { yang ditujukan pada peminjam } \\
\text { oleh direktur untuk membatasi } \\
\text { aktivitas yang mungkin } \\
\text { merusak nilai pinjaman dan } \\
\text { recovery pinjaman (Cochran, } \\
\text { 2001). }\end{array}$ & $\begin{array}{l}\text { Proksi yang digunakan debt } \\
\text { covenant yaitu leverage melalui } \\
\text { debt to equity ratio (DER) yang } \\
\text { dirumuskan : } \\
D E R=\frac{\text { Total Utang }}{\text { Total Ekuitas }} \times 100 \% \\
\text { (Nuradila \& Wibowo, 2018) }\end{array}$ \\
\hline 3. & $\begin{array}{l}\text { Tax } \\
\text { Minimization }\end{array}$ & $\begin{array}{lr}\text { Tax } & \text { minimization } \\
\text { merupakan strategi untuk } \\
\text { meminimalkan beban pajak } \\
\text { terutang melalui tindakan } \\
\text { transfer biaya dan pada } \\
\text { akhirnya } & \text { transfer } \\
\text { pendapatan ke } \quad \text { negara }\end{array}$ & $\begin{array}{l}\text { Tax minimization diproksikan } \\
\text { dengan Effective Tax } \\
\text { Rate (ETR). } \\
\text { ETR } \\
=\frac{\text { Beban Pajak }}{\text { Laba Sebelum Pajak }} \times 100 \%\end{array}$ \\
\hline
\end{tabular}


Jurnal Akuntansi Bisnis, Vol. 18, No. 2, September 2020

ISSN 1412-775X (media cetak) | 2541-5204 (media online)

\begin{tabular}{|c|c|c|c|}
\hline & & $\begin{array}{l}\text { dengan tarif pajak yang } \\
\text { rendah (Hartati et al., 2015). }\end{array}$ & (Nuradila \& Wibowo, 2018) \\
\hline 4. & $\begin{array}{l}\text { Kualitas } \\
\text { Audit }\end{array}$ & $\begin{array}{l}\text { Kualitas audit merupakan } \\
\text { pemeriksaan yang dilakukan } \\
\text { secara sistematis dan menjaga } \\
\text { sikap independen ketika } \\
\text { melaksanakan suatu pekerjaan } \\
\text { audit dengan menjaga mutu dan } \\
\text { output yang dihasilkan yang } \\
\text { sesuai dengan pengaturan yang } \\
\text { telah direncanakan (Simanjutak, } \\
\text { 2008). }\end{array}$ & $\begin{array}{l}\text { Pengukuran kualitas audit } \\
\text { menggunakan variabel dummy: } \\
\text { Nilai 1: Perusahaan yang diaudit } \\
\text { oleh Kantor Akuntan Publik Big } \\
\text { Four. } \\
\text { Nilai 0: Perusahaan yang tidak } \\
\text { diaudit oleh Kantor Akuntan } \\
\text { Publik Big Four. } \\
\text { (Nugroho et al., 2018) }\end{array}$ \\
\hline 5. & Firm Size & $\begin{array}{l}\text { Firm size yaitu skala } \\
\text { seberapa besar atau kecil } \\
\text { suatu perusahaan yang } \\
\text { dapat } \\
\text { stabilitas, keseimbangan, } \\
\text { dan kemampuan perusahaan } \\
\text { dalam melakukan aktivitas } \\
\text { ekonominya (Nugroho et } \\
\text { al., 2018). }\end{array}$ & $\begin{array}{l}\text { Diproksikan dengan logaritma } \\
\text { natural total asset. } \\
\text { Firm Size }=\text { Ln (Total Asset) } \\
\text { (Nugroho et al., 2018) }\end{array}$ \\
\hline
\end{tabular}

Sumber: Data sekunder yang diolah, 2021

Penelitian ini menggunakan alat analisis berupa IBM SPSS Statistics V.24. Dimana teknik analisisnya memakai analisis statistik deskriptif dan analisis statistika inferensial serta analisis regresi moderasi (Moderated Regresion Analysis) dengan model regresi sebagai berikut.

$$
\mathrm{Y}=\alpha+\beta 1 \mathrm{X} 1+\beta 2 \mathrm{X} 2+\beta 3 \mathrm{X} 3+\beta 4(\mathrm{X} 1 * \mathrm{Z})+\beta 5(\mathrm{X} 2 * \mathrm{Z})+\beta 6(\mathrm{X} 3 * \mathrm{Z})+\mathrm{e}
$$

Keterangan:

- $\quad \mathrm{Y}=$ Transfer Pricing

- $\mathrm{X} 1=$ Debt Covenant

- $\quad \mathrm{X} 2=$ Tax Minimization

- $\quad \mathrm{X} 3=$ Kualitas Audit

- $\mathrm{Z}=$ Ukuran Perusahaan

\section{HASIL DAN PEMBAHASAN}

\section{Statistik Deskriptif}

Penelitian ini diolah menggunakan analisis deskriptif dan inferensial. Berikut hasil dari analisis deskriptif dilihat pada Tabel 3 berikut. 
Tabel 3. Statistik Deskriptif

\begin{tabular}{|c|r|c|c|c|c|}
\hline Variabel & $\mathbf{N}$ & Minimum & Maksimum & $\begin{array}{c}\text { Rata- } \\
\text { Rata }\end{array}$ & $\begin{array}{c}\text { Dev. } \\
\text { Std }\end{array}$ \\
\hline $\begin{array}{c}\text { Transfer } \\
\text { Pricing }\end{array}$ & 51 & 0,00043 & 0,957 & 0,247 & 0,285 \\
\hline $\begin{array}{c}\text { Debt } \\
\text { covenant }\end{array}$ & 51 & 0,119 & 1,907 & 0,829 & 0,493 \\
\hline $\begin{array}{c}\text { Tax } \\
\text { minimization }\end{array}$ & 51 & 0,151 & 0,462 & 0,286 & 0,066 \\
\hline $\begin{array}{c}\text { Kualitas } \\
\text { Audit }\end{array}$ & 51 & 0 & 1 & 0,67 & 0,476 \\
\hline Firm Size & 51 & 27,009 & 32,258 & 29,461 & 1.372 \\
\hline
\end{tabular}

Sumber: Output SPSS

Berdasarkan tabel 3 di atas, huruf $\mathrm{N}$ menunjukkan jumlah observasi yang digunakan dalam penelitian ini yaitu 51 observasi di perusahaan pertambangan. Nilai minimum transfer pricing sebesar 0,00043 yang dimiliki oleh PT Adaro Energy Tbk (ADRO) pada tahun 2017. Kondisi tersebut menunjukkan bahwa PT ADRO melakukan transaksi dengan pihak berelasi paling rendah dibanding dengan perusahaan sampel lainnya. Nilai maksimum transaksi transfer pricing dimiliki oleh PT Samindo Resources Tbk (MYOH) dengan nilai sebesar 0,957 pada tahun 2019 yang berarti bahwa PT MYOH terindikasi lebih sering melakukan transfer pricing. Hal ini menunjukkan perusahaan tersebut lebih memaksimalkan transaksi dengan pihak berelasi secara lebih intens dibanding perusahaan sampel lainnya.

Nilai rata-rata transfer pricing sebesar 0,247 yang berarti bahwa sebesar 24,72\% transaksi piutang dikategorikan sebagai transaksi transfer pricing dengan pihak berelasi dan mempunyai nilai standar deviasi sebesar 0,285 yang berarti kecenderungan data transfer pricing antara perusahaan satu dengan perusahaan yang lain selama periode pengamatan mempunyai tingkat penyimpangan sebesar 0,285. Dari hasil analisis statistik deskriptif diketahui bahwa nilai standar deviasi lebih besar dari rata-rata sehingga sebaran data tersebut bersifat heterogen atau dapat dikatakan kurang baik. Hal ini terjadi dikarenakan ada kesenjangan yang cukup besar antara nilai minimum dengan nilai maksimum.

Dari Tabel 3 dapat juga dilihat bahwa debt covenant mempunyai nilai minimum 0,119 yang dimiliki oleh PT Harum Energy Tbk (HRUM) pada tahun 2019. Kondisi tersebut menunjukkan bahwa PT HRUM mempunyai rasio utang paling rendah dibanding perusahaan sampel lainnya, yang berarti perusahaan tersebut jauh dari kemungkinan untuk melanggar perjanjian utang. Nilai maksimum debt covenant dimiliki oleh PT Petrosea Tbk (PTRO) dengan nilai sebesar 1,907 pada tahun 2018 yang berarti bahwa PT PTRO mempunyai rasio utang yang lebih tinggi dibanding perusahaan sampel lainnya. Secara teoritis dapat disimpulkan bahwa perusahaan tersebut telah mendekati masa untuk mengakhiri perjanjian utang dan kemungkinan telah membuat manajer untuk memilih prosedur akuntansi yang dapat meningkatkan laba.

Nilai rata-rata debt covenant sebesar 0,829 menunjukkan bahwa perusahaan pertambangan mempunyai rata-rata tingkat utang sebesar $82,9 \%$ dari total utang. Nilai standar deviasi variabel debt covenant sebesar 0,493 yang berarti nilai standar deviasi lebih kecil daripada rata-rata hitungnya. Hal ini menunjukkan bahwa debt covenant mempunyai 
sebaran data yang relatif sama atau homogen, sehingga dapat dikatakan data tersebut cukup baik karena sampel berada pada daerah rata-rata perhitungannya.

Tabel 3 juga menunjukkan bahwa tax minimization mempunyai nilai minimum sebesar 0,151 yang dimiliki oleh PT Ifishdeco Tbk (IFSH) pada tahun 2018. Hal ini berarti perusahaan tersebut mempunyai rasio beban pajak paling rendah diantara sampel lainnya. Nilai maksimum tax minimization sebesar 0,462 dimiliki oleh PT Radiant Utama Interinsco Tbk (RUIS) pada tahun 2017. Hal ini menunjukkan bahwa perusahaan tersebut mempunyai beban pajak yang paling tinggi diantara sampel lainnya. Nilai rata-rata tax minimization yaitu 0,286 yang menunjukkan bahwa rata-rata tingkat rasio pembayaran pajaknya sebesar $28,6 \%$. Sementara standar deviasinya sebesar 0,066 yang berarti lebih kecil dari rata-rata hitungnya. Kondisi tersebut menunjukkan bahwa sebaran data pada variabel tax minimization mempunyai variabilitas yang rendah atau bersifat homogen. Sehingga dapat dikatakan data tersebut cukup baik karena sampel berada pada daerah rata-rata perhitungannya.

Dari Tabel 3 juga dapat dilihat bahwa nilai maksimum kualitas audit sebesar 1 menunjukkan perusahaan yang diaudit KAP Big 4 dan nilai minimum 0 menunjukkan perusahaan yang diaudit KAP NonBig 4. Nilai rata-rata kualitas audit sebesar 0,67 menunjukkan bahwa $67 \%$ dari 51 observasi perusahaan atau 34 perusahaan telah diaudit KAP Big 4. Nilai standar deviasi sebesar 0,476 kecil dibanding rata-rata yang berarti bahwa sebaran data pada variabel kualitas audit tergolong rendah atau homogen. Sehingga dapat dikatakan data tersebut cukup baik karena sampel berada pada daerah rata-rata perhitungannya.

Tabel 3 juga menunjukkan firm size mempunyai nilai minimum sebesar 27,009 yang dimiliki oleh PT Bornea Olah Sarana Sukses Tbk (BOSS) tahun 2018. Sementara nilai maksimumnya sebesar 32,258 yang dimiliki oleh PT Adaro Energy Tbk (ADRO) pada tahun 2018. Kondisi tersebut menunukkan bahwa PT ADRO mempunyai kapitalisasi pasar yang tinggi dilihat dari total aset yang dimilikinya jika dibanding perusahaan sampel lainnya. Nilai rata-rata firm size sebesar 29,4616141 dan nilai standar deviasinya sebesar 1,37151333 menunjukkan bahwa sebaran data variabel firm size mempunyai variabilitas yang rendah atau bersifat homogen. Sehingga dapat dikatakan data tersebut cukup baik karena sampel berada pada daerah rata-rata perhitungannya.

Sebelum dilakukan uji hipotesis perlu melakukan uji asumsi klasik terlebih dahulu guna memenuhi kriteria dari kata bias. Hasilnya membuktikan bahwa data bersifat normal, terbebas dari gejala multikolinearitas, tidak terdapat gejala autokorelasi, dan tidak terjadi gangguan heteroskedastisitas. Nilai adjust R-square sebesar 0,323 yang berarti 32,3\% variabel transfer pricing dipengaruhi oleh variabel debt covenant, tax minimization, dan kualitas audit, serta interaksi dari debt covenant, tax minimization dan kualitas audit dengan variabel moderating yaitu firm size, sedangkan sisanya sebesar 67,7\% dipengaruhi oleh variabel lain yang tidak diuji dalam penelitian ini. Tabel 4. menyajikan hasil pengujian hipotesis dengan uji Regresi Moderasi dan hasil ringkasan dapat dilihat pada Tabel 5. 
Jurnal Akuntansi Bisnis, Vol. 18, No. 2, September 2020

ISSN 1412-775X (media cetak) | 2541-5204 (media online)

Tabel 4. Uji Regresi Moderasi (MRA)

\begin{tabular}{|c|c|c|c|c|c|}
\hline \multirow{2}{*}{ Variabel } & \multicolumn{2}{|c|}{$\begin{array}{c}\text { Unstandardized } \\
\text { Coefficients }\end{array}$} & $\begin{array}{c}\text { Standardized } \\
\text { Coefficients }\end{array}$ & Sig. \\
\cline { 2 - 5 } & B & Std. Error & Beta & \\
\hline (Constant) &, 670 &, 204 & & 3,279 &, 002 \\
\hline Debt Covenant & 2,604 & 1,749 & 4,503 & 1,488 &, 144 \\
\hline Tax Minimization & $-14,115$ & 6,283 & $-3,289$ & $-2,247$ &, 030 \\
\hline Kualitas Audit & 6,976 & 1,779 & 11,641 & 3,921 &, 000 \\
\hline X1_Z &,- 090 &, 061 & $-4,474$ & $-1,491$ &, 143 \\
\hline X2_Z &, 441 &, 213 & 3,308 & 2,068 &, 045 \\
\hline X3_Z &,- 237 &, 060 & $-11,859$ & $-3,955$ &, 000 \\
\hline
\end{tabular}

Tabel 5. Ringkasan Pengujian Hipotesis

\begin{tabular}{|c|l|c|c|c|c|}
\hline \multicolumn{2}{|c|}{ Keterangan } & B & Sign. & Alpha & Simpulan \\
\hline H1 & $\begin{array}{l}\text { Debt covenant berpengaruh } \\
\text { positif dan signifikan } \\
\text { terhadap transfer pricing. }\end{array}$ & 2,604 & 0,05 & 0,144 & Ditolak \\
\hline H2 & $\begin{array}{l}\text { Tax minimization } \\
\text { berpengaruh negatif dan } \\
\text { signifikan terhadap transfer } \\
\text { pricing. }\end{array}$ & 14,115 & 0,05 & 0,030 & Diterima \\
\hline H3 & $\begin{array}{l}\text { Kualitas audit berpengaruh } \\
\text { negatif dan signifikan } \\
\text { terhadap transfer pricing. }\end{array}$ & 6,976 & 0,05 & 0,000 & Ditolak \\
\hline H4 & $\begin{array}{l}\text { Firm size mampu } \\
\text { memoderasi secara positif } \\
\text { dan signifikan pengaruh } \\
\text { debt covenant terhadap } \\
\text { transfer pricing. }\end{array}$ & $-0,09$ & 0,05 & 0,143 & Ditolak \\
\hline H5 & $\begin{array}{l}\text { Firm size mampu } \\
\text { memoderasi secara positif } \\
\text { dan signifikan pengaruh tax } \\
\text { minimization terhadap } \\
\text { transfer pricing. }\end{array}$ & 0,441 & 0,05 & 0,045 & Diterima \\
\hline
\end{tabular}




\begin{tabular}{|l|l|l|l|l|l|}
\hline H6 & $\begin{array}{l}\text { Firm size mampu } \\
\text { memoderasi secara negatif }\end{array}$ & & & & \\
& $\begin{array}{l}\text { dan signifikan pengaruh } \\
\text { kualitas audit terhadap } \\
\text { transfer pricing. }\end{array}$ & $-0,237$ & 0,05 & 0,000 & Diterima \\
\hline
\end{tabular}

Sumber: Data sekunder yang diolah, 2021

\section{Pengaruh Debt Covenant Terhadap Tansfer Pricing}

Hipotesis pertama yang menyatakan debt covenant berpengaruh positif dan signifikan terhadap transfer pricing ditolak. Hasil penelitian ini menunjukkan bahwa debt covenant tidak berpengaruh terhadap transfer pricing dikarenakan nilai signifikansi variabel debt covenant lebih besar dari 0,05. Kondisi ini menjelaskan bahwa debt covenant yang diukur menggunakan Debt to Equity Ratio (DER) tidak berpengaruh terhadap transfer pricing yang diukur menggunakan Related Party Transaction (RPT) pada perusahaan pertambangan di Indonesia. Salah satu alasan yang mengakibatkan debt covenant tidak berpengaruh terhadap praktik transfer pricing kemungkinan dikarenakan terbitnya peraturan yang tertuang dalam PMK-169/PMK.010/2015 tentang Penentuan Besarnya Perbandingan antara Utang dan Modal Perusahaan untuk Keperluan Perhitungan Pajak Penghasilan pada pasal 2 ayat (1).

Hipotesis pertama pada penelitian ini tidak didukung oleh the debt covenant hypothesis dalam teori akuntansi positif. Semakin dekat perusahaan dengan pelanggaran perjanjian utang, maka semakin kecil kemungkinan perusahaan untuk menggunakan metode akuntansi yang melaporkan laba periode masa depan ke periode saat ini. Hal tersebut dikarenakan, perusahaan akan lebih berhati-hati dalam pengambilan keputusan supaya tidak melanggar perjanjian utang yang telah disepakati sebelumnya, yang mengakibatkan perusahaan kurang tertarik untuk menggunakan metode akuntansi yang dapat meningkatkan laba perusahaan, misalnya dalam bentuk praktik transfer pricing.

Hasil dari penelitian ini didukung oleh Sari \& Mubarok (2018); Yulianti \& Rachmawati (2019) yang menyatakan bahwa debt covenant mempunyai arah negatif dan tidak berpengaruh signifikan terhadap transfer pricing. Sejalan dengan Sundari \& Susanti (2016), tingkat rasio leverage yang tinggi pada perusahaan sampel tidak mempengaruhi keputusan perusahaan untuk melakukan transfer pricing. Namun, hasil penelitian ini bertentangan dengan penelitian Rosa et al., (2017) dan Nuradila \& Wibowo (2018) yang menunjukkan debt covenant berpengaruh terhadap transfer pricing.

\section{Pengaruh Tax Minimization Terhadap Tansfer Pricing}

Hipotesis kedua yang menyatakan tax minimization berpengaruh negatif dan signifikan terhadap transfer pricing diterima. Hasil penelitian ini menunjukkan bahwa tax minimization yang diukur dengan Effective Tax Rate (ETR) mempunyai pengaruh negatif terhadap transfer pricing pada perusahaan pertambangan di Indonesia. Hasil tersebut berarti semakin tinggi tingkat minimalisasi pajak oleh perusahaan, maka indikasi transfer pricing yang dilakukan oleh perusahaan semakin rendah. Berlaku juga sebaliknya, semakin rendah tingkat minimalisasi pajak perusahaan, maka indikasi trasnfer pricing akan semakin tinggi.

Teori keagenan (agency theory) mendukung hasil hipotesis ini, yang menjelaskan adanya ketimpangan informasi yang terjadi antara pemegang saham (prinsipal) dengan 
manajemen perusahaan (agen). Pihak manejemen berusaha untuk menyembunyikan informasi yang diduga dapat merugikan kepentingan pemegang saham. Menurut Jafri \& Mustikasari (2018), dalam upaya meminimalkan pembayaran pajaknya, perusahaan lebih memilih melakukan transaksi dengan pihak afiliasinya yang ada di negara tax heaven. Kondisi ini memberikan dampak berkurangnya harapan pemegang saham untuk mendapatkan keuntungan dari operasional perusahaan akibat perilaku oportunisik tersebut. Maka dari itu, untuk memberikan kesejahteraan kepada pemegang saham, pihak manajer berupaya untuk melakukan sebuah perencanaan tanpa melakukan manipulasi pada laporan keuangan dalam bentuk transfer pricing.

Tax minimization pada penelitian ini berpengaruh negatif signifikan terhadap transfer pricing, berarti dalam menurunkan kewajiban pajaknya, perusahaan harus melakukan suatu perencanaan perpajakan dengan harapan pajak yang dibayarkan dapat diminimalisir dan citra perusahaan tetap baik. Hasil penelitian ini didukung oleh Merle et al., (2019), Susanti \& Firmansyah (2018) dan Melani (2016) yang menyatakan tax minimization berpengaruh signifikan negatif terhadap transfer pricing. Namun, hasil ini bertentangan dengan penelitian Alino \& Lane (2015), Hartati et al., (2015), serta Nazihah et al., (2019) yang menemukan bahwa pajak berpengaruh positif signifikan terhadap transfer pricing.

\section{Pengaruh Kualitas Audit Terhadap Tansfer Pricing}

Hipotesis ketiga penelitian ini yang menyatakan kualitas audit berpengaruh negatif dan signifikan terhadap transfer pricing ditolak. Hasil dari uji hipotesis menunjukkan kualitas audit berpengaruh positif dan signifikan terhadap transfer pricing, yang berarti peningkatan kualitas audit juga akan meningkatkan indikasi perusahaan melakukan transfer pricing pada perusahaan pertambangan di Indonesia. Menurut Mayantya (2018) alasan kualitas audit berpengaruh positif terhadap transfer pricing karena semakin baik KAP yang digunakan oleh perusahaan akan lebih cenderung dipercayai oleh fiskus, dikarenakan KAP tersebut mempunyai reputasi yang baik dan integritas yang tinggi, namun apabila perusahaan dapat memberikan keuntungan dan kesejahteraan yang lebih baik terhadap KAP yang mempunyai reputasi yang baik, kemungkinan KAP tersebut bisa melakukan kerjasama dengan perusahaan yang diaudit agar tidak terdeteksi adanya transfer pricing.

Teori agensi mendukung penelitian ini yang menyatakan bahwa pemegang saham (prinsipal) akan mengeluarkan biaya agensi yang berupa biaya audit terhadap laporan kinerja manajemen yaitu laporan keuangan dan laporan tahunan. Salah satu bentuk kecurangan untuk memaksimalkan laba yaitu dengan penghindaran pajak melalui transfer pricing. Dimana terdapat asumsi bahwa audit yang dilakukan oleh KAP besar akan lebih berkualitas hasil auditnya. Laporan keuangan dan laporan tahunan yang telah diaudit oleh KAP besar yang berkualitas baik akan lebih dipercaya oleh pihak pemegang saham (pinsipal). Oleh karena itu, ukuran KAP dijadikan sebagai penentu hasil audit dalam pengambilan keputusan perusahaan terindikasi praktik transfer pricing.

Penelitian ini sejalan dengan hasil penelitian dari Rosa et al., (2017) yang menyatakan bahwa good corporate governance yang diproksikan dengan kualitas audit berpengaruh positif dan signifikan terhadap transfer pricing. Selaras dengan penelitian dari Mayantya (2018) yang menyatakan bahwa kualitas audit mempunyai pengaruh positif dan signifikan terhadap transfer pricing. Hasil penelitian ini berbeda dengan penelitian yang dilakukan oleh Eksandy (2017) yang menyatakan bahwa kualitas audit berpengaruh negatif dan signifikan terhadap transfer pricing. 


\section{Firm Size Sebagai Pemoderasi Hubungan Antara Debt Covenant dan Transfer Pricing}

Hipotesis keempat yang menyatakan bahwa firm size memoderasi secara positif dan signifikan pengaruh debt covenant terhadap transfer pricing ditolak. Hasil uji moderasi yang dibuktikan dengan nilai signifikansi dan koefisien regresi menjelaskan bahwa firm size menunjukkan arah negatif dan tidak signifikan, yang berarti firm size tidak mampu memoderasi hubungan antara debt covenant dengan transfer pricing pada perusahaan pertambangan di Indonesia. Semakin banyak jumlah utang yang dimiliki oleh perusahaan besar, maka perusahaan semakin tidak terindikasi melakukan hubungan dengan pihak berelasi dalam bentuk transfer pricing.

Teori akuntansi positif bagian hipotesis perjanjian utang (the debt covenant hypothesis) tidak mendukung hasil dari penelitian ini. Pendapat bahwa utang dapat dimanfaatkan sebagai item yang dapat dikurangkan dari pajak dalam laporan keuangan, khususnya di bagian pengeluaran dalam laporan laba rugi tidak sejalan dalam penelitian ini. Pendanaan yang berasal dari utang yang tinggi akan meningkatkan beban utang yang tinggi, sehingga beban perusahaan meningkat. Hal ini dapat mengurangi laba sebelum kena pajak, sehingga beban pajak yang dibayarkan akan semakin kecil. Jika dikaitkan dengan firm size, hal tersebut tidak dapat diterapkan pada perusahaan-perusahaan yang skalanya cukup besar, hal ini dikarenakan mereka akan menjadi sorotan berbagai pihak terutama para investor. Alasan tersebut yang menyebabkan firm size tidak mampu memoderasi hubungan debt covenant dengan transfer pricing.

Hasil yang menunjukkan bahwa firm size tidak memoderasi pengaruh hubungan debt covenant dengan transfer pricing mengartikan bahwa dengan kehadiran firm size pada penelitian ini tidak mampu memperkuat atau memperlemah pengaruh praktik transfer pricing yang dilakukan perusahaan pertambangan di Indonesia. Peran firm size terhadap hubungan antara debt covenant dan transfer pricing dapat terlihat dari pengawasan kreditur terhadap kinerja perusahaan. Angka utang yang tinggi dapat meningkatkan resiko kekurangan dalam memenuhi kewajiban membayar utang bagi perusahaan. Hal ini juga memungkinkan adanya kenaikkan biaya bunga dan kenaikan biaya pajak, di mana alokasi utang perusahaan diperuntukkan bagi keperluan investasi sehingga mendapatkan penghasilan di luar usaha perusahaan dan membuat laba yang didapat perusahaan naik dan mempengaruhi kenaikan beban pajak yang ditanggung perusahaan.

\section{Firm Size Sebagai Pemoderasi Hubungan Tax Minimization dan Transfer Pricing}

Hipotesis kelima yang menyatakan firm size memoderasi secara positif dan signifikan pengaruh tax minimization terhadap transfer pricing diterima. Hasil uji moderasi yang dibuktikan dengan nilai signifikansi dan koefisien regresi menjelaskan bahwa firm size menunjukkan arah positif dan signifikan, yang berarti firm size mampu memoderasi pengaruh tax minimization dengan transfer pricing pada perusahaan pertambangan di Indonesia. Maksudnya firm size dapat memperkuat hubungan antara tax minimization dengan transfer pricing seperti yang telah diketahui sebelumnya pada hipotesis kedua yang menyatakan ada hubungan negatif dan signifikan antara variabel keduanya.

Semakin rendah tax minimization, maka semakin tinggi tingkat transfer pricing. Begitu juga sebaliknya, semakin tinggi tax minimization, maka semakin rendah tingkat transfer pricing yang terjadi. Jika dikaitkan dengan adanya firm size sebagai pemoderasi, perusahaan yang mempunyai ukuran besar akan lebih banyak melakukan transaksi dengan pihak 
afiliasinya untuk mengalihkan pendapatan dari perusahaan induk ke perusahaan anak. Sehingga ketika pajak yang dibayarkan oleh perusahaan rendah, kemungkinan besar perusahaan telah melakukan pengalihan pendapatan dengan cara transfer pricing.

Teori agensi mendukung hasil hipotesis penelitian ini yang menyatakan bahwa sumber daya yang dimiliki perusahaan akan digunakan manajemen untuk melakukan menimalisasi pajak yang harus dibayarkan oleh perusahaan dan kemudian akan memaksimalkan kinerja perusahaan. Manajer perusahaan melakukan tindakan yang dapat memaksimalkan laba dengan menggunakan tax planning salah satunya melalui tax minimization. Teori agensi ini menggambarkan adanya asimetri infirmasi dimana semua pihak mementingkan dirinya sendiri. Apabila dihubungkan dengan variabel moderasinya, firm size yang besar dianggap lebih terpercaya daripada perusahaan kecil. Sehingga keadaan ini memicu manajer (agen) dalam memanfaatkan aturan perpajakan untuk kepentingan perusahaan yang dapat memaksimalkan laba dengan tax minimization, tanpa memperdulikan atau melihat dari sisi pemerintah (prinsipal).

Penelitian ini menunjukkan bahwa firm size mampu memoderasi pengaruh tax minimization terhadap transfer pricing. Hal tersebut diduga karena besar atau kecilnya perusahaan dapat menentukan perusahaan tersebut melakukan praktik transfer pricing. Nilai rata-rata tax minimization yang dihitung menggunakan effective tax rate (ETR) pada perusahaan sampel yaitu sebesar $82,88 \%$ dan rata-rata transfer pricing yang dihitung menggunaka related party transaction (RPT) sebesar $24,72 \%$, yang mana bahwa semakin tinggi tax minimization yang digunakan oleh perusahaan sampel, maka semakin rendah transfer pricing, yang menyebabkan variabel firm size mampu memoderasi hubungan antara tax minimization dengan indikasi perusahaan melakukan praktik transfer pricing.

\section{Firm Size Sebagai Pemoderasi Hubungan Antara Kualitas Audit dan Transfer Pricing}

Hipotesis keenam yang menyatakan firm size memoderasi secara negatif dan signifikan pengaruh kualitas audit terhadap transfer pricing diterima. Hasil uji moderasi yang dibuktikan dengan nilai signifikansi dan koefisien regresi menjelaskan bahwa firm size menunjukkan arah negatif dan signifikan, yang berarti firm size mampu memoderasi pengaruh tax minimization dengan transfer pricing pada perusahaan pertambangan di Indonesia. Maksudnya firm size dapat memperlemah hubungan antara kualitas audit dengan transfer pricing seperti yang telah diketahui sebelumnya pada hipotesis ketiga yang menyatakan ada hubungan positif dan signifikan antara variabel keduanya. Semakin tinggi kualitas audit, maka semakin tinggi tingkat transfer pricing. Jadi, apabila firm size tinggi maka kualitas audit juga akan tinggi dan indikasi perusahaan dalam melakukan praktik transfer pricing akan semakin menurun.

Teori keagenan tidak mendukung hasil hipotesis penelitian ini. Dalam teori keagenan, untuk menghasilkan audit yang berkualitas, seorang principal akan cenderung menunjuk agen (auditor) yang memiliki independensi. Auditor yang mempunyai independensi tinggi diduga auditor yang berada dalam lingkup KAP yang besar. Dimana terdapat asumsi bahwa audit yang dilakukan oleh KAP besar akan lebih berkualitas hasil auditnya (Nugroho et al. 2018). Laporan keuangan dan laporan tahunan yang telah diaudit oleh KAP besar yang berkualitas baik akan lebih dipercaya oleh pihak pemegang saham (pinsipal). Adanya firm size dan penggunaan KAP besar menjadikan citra perusahaan telihat lebih baik, sehingga semakin besar firm size maka perusahaan tersebut akan menggunakan KAP dengan peringkat tertinggi juga, yang mana dapat menurunkan tingkat transfer pricing. 
Hasil penelitian ini sesuai dengan hipotesis yang diajukan, dimana dengan penambahan moderasi firm size dapat memperlemah hubungan kualitas audit dengan transfer pricing. Hal ini dikarenakan tidak hanya KAP berlabel The Big 4 saja yang mempunyai hasil yang baik dan kredibilitas yang tinggi, akan tetapi semua KAP harus menerapkan pedoman, prosedur dan regulasi dalam mengaudit laporan keuangan. Terbukti juga bahwa kualitas audit bukanlah dasar perusahaan melakukan transfer pricing (Nugroho et al. 2018). Menurut Erawati \& Fidiana (2020), auditor eksternal juga harus bertanggungjawab atas opini yang diberikan. Opini tersebut didasarkan pada kesesuaian perusahaan dalam melaporkan laporan keuangannya.

\section{SIMPULAN DAN SARAN}

\section{Simpulan}

Berdasarkan hasil penelitian membuktikan bahwa debt covenant tidak berpengaruh siginifikan terhadap transfer pricing, tax minimization berpengaruh negatif signifikan terhadap transfer pricing, kualitas audit berpengaruh positif signifikan terhadap transfer pricing, firm size tidak mampu memoderasi hubungan debt covenant terhadap transfer pricing, namun mampu memoderasi tax minimization dan kualitas audit terhadap transfer pricing pada perusahaan pertambangan di Indonesia. Berdasarkan hasil penelitian, tax minimization berpengaruh negatif signifikan terhadap transfer pricing. Oleh sebab itu, pihak manajemen perusahaan dapat mengontrol dan melakukan perencanaan dengan minimalisasi pajak yang sesuai peraturan agar perusahaan dapat menekan beban pajak yang dikeluarkan dan mendapatkan laba yang maksimal. Selain itu, hasil pengujian menunjukkan koefisien determinasi hanya 32,3\% saja praktik transfer pricing dipengaruhi oleh variabel di atas. Sisanya sebanyak $67,7 \%$ praktik transfer pricing dipengaruhi oleh variabel lain.

\section{Saran}

Penelitian selanjutnya diharapkan dapat menggunakan pengukuran atau variabel lain seperti sales growth dan thin capitalism yang diduga dapat mempengaruhi praktik transfer pricing. Keterbatasan penelitian ini terdapat pada pemilihan populasi yang dijadikan objek pengamatan terlalu sedikit, sehingga perlu menambahkan berbagai sektor lain seperti sektor perdagangan dan aneka industri yang masih jarang diteliti dalam kasus ini.

\section{DAFTAR PUSTAKA}

Alino, N.U., and S. Lane. 2015. A Conceptual Model of the Effects of Taxation, Exchange Rate, and Regulations on the Transfer Pricing Behavior of Multinational Firm Managers By. Journal of Comparative International Management 18 (1): 24-36.

DeAngelo, L.E. 1981. Auditor Size and Audit Quality. Journal of Accounting and Economics 3 (3): 183-99.

Eksandy, A. 2017. Pengaruh Komisaris Independen, Komite Audit, Dan Kualitas Audit Terhadap Penghindaran Pajak (Tax Avoidance). Competitive 1 (1): 1-20.

Erawati, N., and Fidiana. 2020. Pengaruh Beban Pajak, Tunneling Incentive, Mekanisme 
Bonus, Kualitas Audit Terhadap Transfer Pricing. Jurnal Ilmu Dan Riset Akuntansi 9 (1): $1-25$.

F, D.N., Y. Mayowan., and S. Karjo. 2016. Transfer Pricing Happen on the Company with High Profit Purpose and Using Tax Avoidance Become the a to Fulfil It . Ownership Stucture Is Also Affect Management to Transfer Wealth the Themeself or to Majority Stakeholder. The Company That Applying Good C. Jurnal Perpajakan (JEJAK) 8 (1): $1-9$.

Hartati, W., Desmiyawati., and Julita. 2015. Tax Minimization, Tunneling Incentive dan Mekanisme Bonus Terhadap Keputusan Transfer Pricing Seluruh Perusahaan Yang Listing Di Bursa Efek Indonesia. Universitas Riau, Indonesia.

Jafri, H.E., and E. Mustikasari. 2018. Pengaruh Perencaan Pajak, Tunneling Incentive dan Aset Tidak Berwujud Terhadap Perilaku Transfer Pricing Pada Perusahaan Manufaktur Yang Memiliki Hubungan Istimewa Yang Terdaftar Di Bursa Efek Indonesia Periode 2014-2016. Berkala Akuntansi Dan Keuangan Indonesia 03 (02): 63-77.

Jensen, M., and W. Meckling. 1976. Theory of the Firm: Managerial Behavior, Agency Costs and Ownership Structure. Journal of Financial Economics 3 (4): 305-60.

Khairunisa, K., D.W. Hapsari., and W. Aminah. 2017. Kualitas Audit, Corporate Social Responsibility, dan Ukuran Perusahaan Terhadap Tax Avoidance. Jurnal Riset Akuntansi Kontemporer 9(1):39-46. doi: 10.23969/jrak.v9i1.366.

Mayantya, S. 2018. Pengaruh Tax Minimization, Mekanisme Bonus, Kepemilikan Asing, Exchange Rate, dan Kualitas Audit Terhadap Keputusan Transfer Pricing (Studi Pada Perusahaan Manufaktur Yang Terdaftar Di Bursa Efek Indonesia Periode 2014-2016). Skripsi. Universitas Islam Indonesia, Yogyakarta.

Melani, A., and B.Y. Tulus. 2019. Adaro Tersandung Kasus Dugaan Penggelapan Pajak USD 14 Juta Tiap Tahun Sejak 2009. Diakses pada 21 January 2021, dari https://www.merdeka.com/uang/adaro-tersandung-kasus-dugaan-penggelapan-pajakusd-14-juta-tiap-tahun-sejak-2009.html.

Melani, T. 2016. Pengaruh Tax Minimization, Mekanisme Bonus, Tunneling Incentive dan Ukuran Perusahaan Terhadap Keputusan Melakukan Transfer Pricing. Skripsi. Universitas Islam Negeri Syarif Hidayatullah, Jakarta.

Merle, R., B. Al-gamrh., and T. Ahsan. 2019. Tax Havens and Transfer Pricing Intensity: Evidence from the French CAC 40 Listed Firms Tax Havens and Transfer Pricing Intensity: Evidence from the French CAC-40 Listed Firms. Cogent Business \& Management 6 (1). doi: 10.1080/23311975.2019.1647918.

Mispiyanti. 2015. Pengaruh Pajak, Tunneling Incentive dan Mekanisme Bonus Terhadap Keputusan Transfer Pricing. Jurnal Akuntansi \& Investasi 16 (1): 62-73.

Nazihah, A., Azwardi., and L.L. Fuadah. 2019. The Effect Of Tax, Tunneling Incentive, Bonus Mechanisms, And Firm Size On The Effect Of Tax, Tunneling Incentive, Bonus Mechanisms, And Firm Size On Transfer Pricing (Indonesian Evidence). Journal of Accounting, Finance and Auditing Studies 5(1): 1-17. doi: 10.32602/jafas.2019.0. 
Nugroho, L., B.R. Wicaksono., and W. Utami. 2018. Analysis of Taxes Payment, Audit Quality and Firm Size to The Transfer Pricing Policy in Manufacturing Firm in Indonesia Stock Exchange International Journal of Business Society Transfer Pricing In Manufacturing Firm In Indonesia Stock. International Journal of Business Society 2 (9): 83-93. doi: 10.30566/ijo-bs/2018.288.

Nuradila, R.F., and R.A. Wibowo. 2018. Tax Minimization Sebagai Pemoderasi Hubungan Antara Tunneling Incentive, Bonus Mechanism dan Debt Convenant Dengan Keputusan Transfer Pricing. Journal of Islamic Finance and Accounting (JIFA) 1(1). doi: https://doi.org/10.22515/jifa.v1i1.1135.

Refgia, T., V. Ratnawati., and Rusli. 2017. Pengaruh Pajak, Mekanisme Bonus, Ukuran Perusahaan, Kepemilikan Asing, dan Tunneling Incentive Terhadap Transfer Pricing (Perusahaan Sektor Industri Dasar dan Kimia Yang Listing Di BEI Tahun 2011-2014). JOM Fekon 4 (1): 543-55.

Rosa, R., R. Andini., and K. Raharjo. 2017. Pengaruh Pajak, Tunneling Insentive, Mekanisme Bonus, Debt Covenant dan Good Corporate Gorvernance (GCG) Terhadap Transaksi Transfer Pricing (Studi Pada Perusahaan Manufaktur Yang Terdaftar Di Bursa Efek Indonesia Tahun 2013 - 2015). Universitas Pandanaran Semarang, Indonesia.

Sari, E.P., and A. Mubarok. 2018. Pengaruh Profitabilitas, Pajak, Dan Debt Covenant Terhadap Transfer Pricing (Studi Empiris Perusahaan Manufaktur Terdaftar Di BEI Tahun 2012-2016). Seminar Nasional I Universitas Pamulang, Indonesia.

Septiyani, R.P.P., W. Ramadhanti., and Y.A. Sudibyo. 2018. Some Factors That Affect Transfer Pricing Decision. Soedirman Accounting Review 3 (1): 21-38. doi: https://doi.org/10.20884/1.sar.2018.3.1.1158.

Simanjuntak, P. 2008. Pengaruh Time Budget Pressure Dan Resiko Kesalahan Terhadap Penurunan Kualitas Audit (Reduced Audit Qaulity) (Studi Empiris Pada Auditor Kap di Jakarta).

Sundari, B., and Y. Susanti. 2016. Transfer Pricing Practices: Empirical Evidence From Manufacturing Companies in Indonesia. Asia-Pacific Management Accounting Journal 11 (2): 25-39.

Susanti, A., and A. Firmansyah. 2018. Determinants of Transfer Pricing Decisions in Indonesia Manufacturing Companies. Jurnal Akuntansi Dan Auditing Indonesia 22 (2): 81-93. doi: https://doi.org/10.20885/jaai.vol22. iss2.art1.

Watts, R.L., and J.L. Zimmerman. 1990. Positive Accounting Theory: A Ten Year Perspective. Accounting Review 131-56.

Yulia, A., N. Hayati., and R.M. Daud. 2019. The Influence of Tax , Foreign Ownership and Company Size on the Application of Transfer Pricing in Manufacturing Companies Listed on IDX during 2013-2017. International Journal of Economics and Financial Issues 9 (3): 175-81. doi: https://doi.org/10.32479/ijefi.7640.

Yulianti, S., and S. Rachmawati. 2019. Tax Minimization Sebagai Pemoderasi Pada Pengaruh Tunnelling Incentive dan Debt Convenant Terhadap Ketetapan Transfer 
Jurnal Akuntansi Bisnis, Vol. 18, No. 2, September 2020 ISSN 1412-775X (media cetak) | 2541-5204 (media online)

Pricing. Jurnal Akuntansi Berkelanjutan Indonesia 2 (2): 165-79. doi: http://dx.doi.org/10.32493/JABI.v2i2.y2019.p165-179. 